\title{
Lung adenocarcinoma: a new bipolar masquerader
}

\author{
Abdulrazak Alchakaki, ${ }^{1}$ Mohamad Kabach, ${ }^{2}$ Abdul Hamid Alraiyes, ${ }^{3}$ M Chadi Alraies ${ }^{4}$
}

${ }^{1}$ Henry Ford Macomb, Southfield, Michigan, USA ${ }^{2}$ Department of Medicine, University of Miami Miller, West Palm Beach, Deerfield Beach, Florida, USA ${ }^{3}$ Department of Pulmonary Diseases, Critical Care, \& Environmental Medicine, Tulane University Health Sciences Center, New Orleans, Louisiana, USA

${ }^{4}$ Department of Hospital Medicine, Cleveland Clinic Cleveland, Ohio, USA

\section{Correspondence to} Dr M Chadi Alraies, alraies@hotmail.com
To cite: Alchakaki $\mathrm{A}$, Kabach M, Alraiyes AH, et al. BMJ Case Rep Published online: [please include Day Month Year] doi:10.1136/bcr-2013010085

\section{DESCRIPTION}

A 43-year-old woman, known to have bipolar disorder, presented with 4 months history of change in behaviour and functional status in addition to memory problem. Lately she started to have constant headache, fatigue and multiple episodes of postural syncope. This was associated with nausea, vomiting and weight loss. Her family doctor attributed her symptoms to bipolar disease without seeking further tests. She has a history of 30-pack-year tobacco smoking. Physical examination was remarkable for lethargy, flat affect, in addition to cognition and orientation impairment. The rest of her examination was unremarkable. Head CT scan showed multiple large heterogeneous hypodensities in both frontal lobes. Brain MRI demonstrated large bilateral frontal cystic and solid lesions, consistent with metastatic lesions (figure 1). These lesions were symmetrical around the midline and precluded subfalcine herniation. CT scan of chest abdomen and pelvis showed right lung apex (Pancoast tumour) mass with mediastinal lymphadenopathy (figure 2). Adrenal and liver lesions were detected as well. This was sufficient to stage the tumour and no positron emission tomography scan was performed. CT-guided biopsy of the lung mass was obtained and pathology examination declared poorly differentiated lung adenocarcinoma. TNM score was determined to be T3N2M1 based on imaging and histopathological findings. She underwent 14 sessions of radiation and systemic steroids, which led to partial recovery in her decision-making capacity. Disease extension and prognosis was discussed with the patient and she opted for hospice care only. After 5 weeks, the patient expired at home. In retrospect, it is obvious that she had precocious and unspecific features masquerading as her bipolar disorder. This was

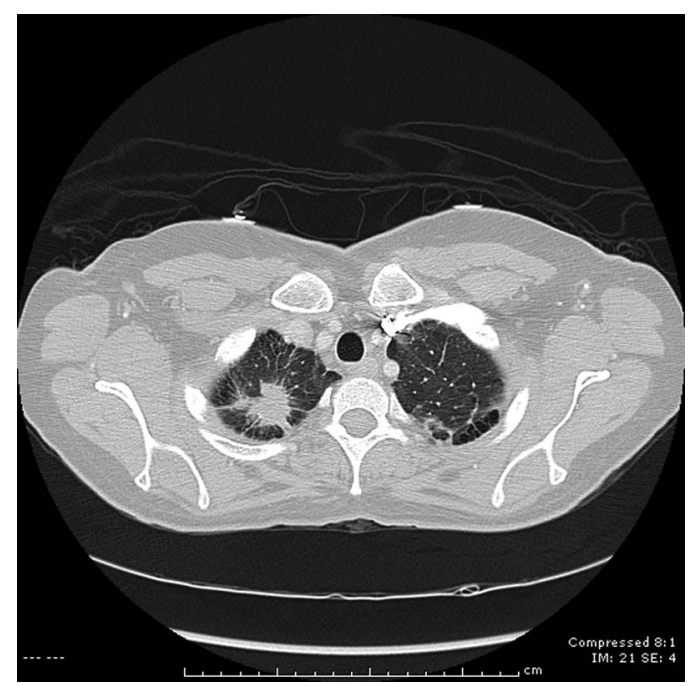

Figure 2 CT scan of chest showed right lung apex (Pancoast tumour) mass with mediastinal lymphadenopathy.

very misleading and, therefore, resulted in major delay in diagnosis and early interventions required to increase survival and improve quality of life. ${ }^{1-3}$

\section{Learning points}

Cystic brain metastases arising from lung adenocarcinoma is very rare.

- Patients presenting with new or worsening neuropsychiatric symptoms should be worked up based on risk stratification for malignancy, infections and degenerative brain processes.

- Synchronous presentation of brain metastasis comprises less than $20 \%$ in patients with cancer.

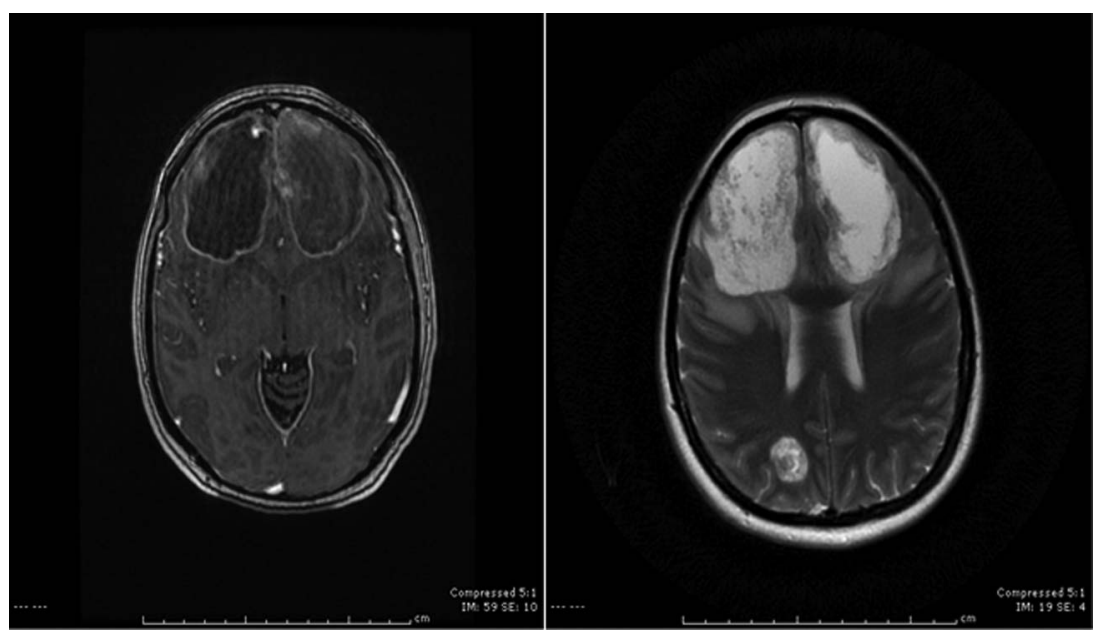

Figure 1 Brain MRI with contrast showing multiple bilateral cerebral and cerebellar cystic and solid lesions, largest in the bilateral anterior-inferior frontal lobes. Surrounding vasogenic oedema is most prominent in the frontal lobes. 
Competing interests None.

Patient consent Obtained.

Provenance and peer review Not commissioned; externally peer reviewed.
2 Ouyang $\mathrm{H}$, Zhou $\mathrm{CW}$, Zhang $\mathrm{HM}$. MRI features of brain metastases of lung cancer. Zhonghua Zhong Liu Za Zhi 2004;26:315-18.

3 Surov A, Hainz M, Kornhuber M. Multiple cystic metastases in the brain from adenocarcinoma of the lung. Am J Med 2009;122:e3-4.

\section{REFERENCES}

1 De Shields MS, Ruether J. Lung carcinoma presenting as multiple cystic lesions in the brain. Del Med J 1998;70:77-80.

Copyright 2013 BMJ Publishing Group. All rights reserved. For permission to reuse any of this content visit http://group.bmj.com/group/rights-licensing/permissions.

BMJ Case Report Fellows may re-use this article for personal use and teaching without any further permission.

Become a Fellow of BMJ Case Reports today and you can:

- Submit as many cases as you like

- Enjoy fast sympathetic peer review and rapid publication of accepted articles

- Access all the published articles

- Re-use any of the published material for personal use and teaching without further permission

For information on Institutional Fellowships contact consortiasales@bmjgroup.com

Visit casereports.bmj.com for more articles like this and to become a Fellow 